\title{
Deep Changes in the Process of Content for Pre-University Education and Its Effects in the Human Development of Albania (1992 -2013)
}

\author{
Jani Sota, Prof. Assoc. Ph.D. \\ "Aleksandër Moisiu" University, Durrës \\ jani_sota@yahoo.com
}

\section{Doi:10.5901/jesr.2014.v4n4p0500}

\begin{abstract}
School is where young people not only begin their professional careers but also establish personalities; construct a vision of the world that surrounds them. During education activity in and out of school environment is given birth and developed a wide and diverse range of interests, among which cognitive learning interests occupy a leading place. Teaching interests are held on the basis of cognitive interests, which constitute the first steps to subsequent development of human capital. Education interests are developed in the content of the integrated learning motives, desires, goals, ideals that requires teachers to accomplish in the instructional and educational activities. Interests with motives are conditioned not only by the overall level of psychosocial development in certain ages but also by professional and scientific interest of students. The structure and contents of teaching interests (school) is developed alongside the widening and deepening for the continuous enrichment of the interior of the learning process from one class to another, the implementation of an advanced teaching technology and learning profound and sustainable knowledge. Formation and development and teaching interests are affected by many factors such as: changes in school documentation consisting of syllabus, curriculum and textbooks and relevant guidelines to help the school and education specialists for effective implementation, which will pave the way for reform of the education system in Albania, especially after the fall of the dictatorship in the 90s. Lesson plans, programs and consequently the relevant texts have had over the last 20 years significant changes in political and social-economic contingent historical context.
\end{abstract}

Keywords: education, curriculum, textbook, human capital, reform, development.

\section{Introduction}

The right to education is a right that has a specific weight to physical development, human development and social capital not only of a country but our planet as a whole.

For this reason the right to education is a right guaranteed in the Universal Declaration of Human Rights (UDHR), the Convention on the Rights of the Child of the United Nations. Universal right to participate in compulsory education is put on top of the list in the millennium goals set by the United Nations. However, participation in a primary education (PE) is still low in many countries of the world. Research shows that in 2000, more than 113 million children have no access to primary education, 880 million adults are illiterate and gender discrimination continues to survive in many educational systems (International fundamental documents for Education and Learning, 2002: 51). Also, "the quality of the learning process and the achievement of human values and skills, and goals are far from necessities of the individual and society" (ibid). These data are the basis for a greater commitment to participation in a universal participation for Primary Education (PE), which has received global measures after meeting at the World Education Forum in 2000 in Dakar, Senegal. (Dakar Framework for Action, April 2000: 2).

Education is considered as one of the basic areas for development, peace and stability between countries and one of the main mechanisms for effective participation in the societies and economies of the $21^{\text {st }}$ century, under the umbrella of the accelerated process of globalization (Beder University of Educational Sciences, Vol. 2, April 2013: 58). But efforts to actively participate not necessarily guarantee quality education, therefore the continuous improvement of the quality education, stability and progress of quality education, should be part of these efforts in stroke imperatives.

In order for "The Quality" and Equality in Education" (the CBA), to be a function of human development and social capital, efficient planning and managing and implementation is required, monitoring and evaluating of proper tracking

\footnotetext{
* The notion of quality education is a broad one, all inclusive and complex that does not concentrate only to national level plan and policies but highlights special importance to implementation of policies at school and class level, as in the case of physical educational environments etc.
} 
transparency and great responsibility input-conditions in which the Pre-University Education (PE) processes are developed as university education, where the results that emerge from the process of education and education as well as the impacts - impacts of these results in physical development, the individual features of learners are essential for economic development, as well as the recognition, observance and enforcement of values that are useful for the social welfare of the citizens for democracy, social justice and the rule of law. Only in this way the CBA functions for human capital development. But for that to happen in this process it should have extensive involvement of actors and partnership with all sections of society. Above all, for high quality, policies, plans and practices, schools should aim to think and address the interests and needs of students and the success of the last goal.

Interests and needs of students, the needs of society for technical developments, technological, and social science, physical development of students, to raise the human development index it should be addressed in the curricula and textbooks, which are not so illustrative and nothing but "Food" for human development and social capital of Albanian society. For this reason, must make continuous improvements in curricula and textbooks for "improving the quality of education certainly requires adapting curriculum content and processes that aim to put the learner at the center, to recognize and apply the diversity of needs, interests and stages of cognitive development, social and emotional development of students and the knowledge, skills and attitudes that enable an individual to learn independence, learning and problem solving under "Education for All" (National Strategy for Pre-University Education Development 2007-2013, 2007: 17). These changes are closely related to human development concepts, since the curriculum is an important contribution for human resource development.

The concept of development means "creating an environment where one can develop their full potential and have a productive life, creative to coincide with the needs and interests" (Epstein, J., Coates, L., Salinas, M., Simon, B., 1997: 184). But the concept of development regards people not as tools but as ends in themselves, human development means "the process of expanding people's choices and opportunities" (ibid). To achieve this, it is thought to have access to knowledge and information, access to material resources for a decent standard of living and free participation in community life are collective issues. However, research has shown that investment in university education in general and curriculum in particular, affect human development, since the content of education, curriculum guides respectively learning process toward goals that determine individual skills and abilities that can revive out in practice.

Reforms of education content in Albania 1993-2010, are aimed and intended to modify the contents of curricula and teaching methods from the perspective of human development and the need for lifelong learning. The main purpose is "to enable children and young Albanian who contribute effectively to prepare the new generation for successful participation and active life in society" (National Strategy for Pre-University Education Development 2007-2013, 2007: 96). But, to achieve this goal, we need a comprehensive and qualitative reform of curricula and textbooks for an efficient and sustainable implementation.

\section{Curricula in Function of Human Development}

The term curriculum* is a relatively new term in the Albanian education. In Albania, educational reform after 1990, spurred not only people's involvement in educational terminology of many new terms, such as educational curriculum, school curriculum based, modular curriculum, the curriculum integrated, etc. subject standard., but also the first production sets the curriculum for all levels of education and subjects to be taught in schools (School-based curriculum. Modular curriculum, 2007: 9). Meanwhile, efforts are continuously ongoing about what schools and teachers should play an active role in the development of their curriculum.

The concept of curriculum has been steadily expanding, going over the boundaries of the content. Change of terminology from the plan - program in the curriculum means that there has been a tendency to change the approach to the content and implementation of Albanian education system content. Development Curriculum conceives how curriculum and its main elements are organized: the subject, the content, teaching methods and materials, experiences and student activities (ibid).

Curricular changes are thought to be closely related to the conception of the curriculum, although what the curriculum and what purpose does it remains a controversial issue. In this context, the curriculum can be seen with a

\footnotetext{
* The term "curriculum" derives from Latin term curre, which mean to run and in ancient Rome was referred to horse racing (course). Traditionally curriculum (or course) is considered the whole content of which the pupil was submitted during his learning experience. These contents were generally represented by school objectives, educational plan, subject program and texts. (Extract from: Bejtja, P., Mustafaj, A., Zagori, E., Dhima, Lindita, Reformng the curricula of Vocational Education System in Albania -study material (1999/2000), Tiranë: 3).
} 
global nature, representing wide range activities and learning experiences (The curriculum on School Basis - Module Curricula, 2007: 11). traditional look from a different angle, this concept is tight and focused primarily "on the content of a course and transfer the content to the learner, initiating close a process of understanding, mainly at the level of object recognition, memorization and repetition of information and knowledge "(ibid: 12). As a result of such an approach, the knowledge of the teacher "transferred" to the student is not "discovered" along with limiting the teaching, learning and assessment in a "correct answer".

Traditional education and the traditional concept of curriculum, changes constantly challenged and not just as a concept but as practice through new development trends of education and liberal democratic curriculum. With new trends, curricula is more comprehensive and wide as concept, exceeding the highest concentration in content and having greater focus on promoting the process of learning to the learner. "Focus on the learner, - by Dwey, an American education - defines curriculum as a field which deals with the experiences of students or active learning" (Hunskin; Ornstein. 2003: 15). The emphasis on student-centered process of teaching and learning objectives means objectives and goals that help transition from memorizing to the facts, events, names, dates, formulas in the curriculum as challenge to thinking, analyzing the ideas and experiences. Such intentions have redesigned the curricula turning it on, as Oakes and Lipton point out, "The real model enabling students to solve problems to create people who know to identify and resolve problems" (Hunskin.; Ornstein., 2003:122). So curriculum changes refrained incline towards connecting of content and experiences of human beings, as well as education is seen as related work experience and community life as Dwey asserts: "School is a miniature of a democratic society where children live, not a place where only learn lessons" (Dewey, John., 2003: 57).

From a different technical perspective, curriculum is defined as "the totality of activities and experiences of formal and informal learning, which students experience with the help and guidance of the school" (Earl. L., Lee, L., 1998: 271). Accepting this general definition force to accept two additional concepts: first, the student is the central element that focuses curriculum (each student has their own curriculum). It is thought that this interpretation is stable, while the students are the ones who often select courses, experiences and other activities accredited in accordance with the needs and of their personal and unique desires, the second formal experiences and activities not considered how to only constituent elements of the curriculum. Such thing means that the learning and professional development is not only performed within the boundaries of class or lab but also formal environments such as student organizations, social clubs or sports, which have significant impact on students' development courses already set that offers a school or training center. These are also new concept based on the changes of education in Albania.

Recent trends of development of advanced curricula in constructive teaching and learning with children at center, which will develop abilities and skills as critical thinking, solving problems, creativity and curiosity, high intellectual abilities, goals that were curricular changes in Albania. As stated in the curriculum framework, the basic document of the curriculum in Albania, "curriculum is assessed as coherent articulation of goals and objectives, contents, methods of teaching and learning and as a basis for evaluation ... and predicts how students should prepare to deal successfully with different challenges in everyday reality " (The curriculum on School Basis - Module Curricula, 2007: 11).

\section{Initiation of Curricular Changes}

Interest curricular changes started in the period after the fall of the dictatorship in the 90s. Albania, as a democratic state switched from a centralized totalitarian state to a legal state, the law and the market economy. No doubt that Albania and national democratic education will be assessed as a matter of priority to emerge as a first step to education reform "exactly not for ideology and depoliticize the school documentation and all areas of school life" (Lulja, E., 2009:37).

Given that the curriculum and teaching process represent the basis of a system of education, system upgrades just start with reviewing the curriculum and modernizing the learning process. Since 1993, pre-university curriculum and teaching-learning process have been and remain subject to continuous improvements. During the last twenty years significant changes in political and social-economic context conditioned by historical, educational reform have been initiated by prioritizing curricular changes considering the status quo of education reform and curricula. The curriculum has been part of a unified system of education in the Republic of Albania, undergoing substantial changes step by step. They found wide coverage especially in social studies. Thus, in the first decade was re-conceptualized most of curricula, being enriched with new concepts and lines aimed at strengthening inter-disciplinary ties (e.g. grouping of technical courses in the subject technology, the extent of knowledge for natural sciences to fifth grade) etc.. (Group of authors, 1995:83).

It should be emphasized that the spectrum of curriculum content is extensive. They include determining the content, objectives and general educational objectives, for cycles or different levels, for specific subjects, methods and 
tools that will be used during the learning process and disposition of assessment (tests, exams) etc.. Therefore, when talked about curriculum reform in Albania and beyond in other ex-communist Central and Eastern Europe, this reform means that all components in their entirety constitute the process of education.

Each country considering educational tradition and the degree of economic and social development, display its image, but is generally from researchers concluded that the directions quoted below are common phenomena from which the Albanian education was no exception. Among the most important, it was possible to change the overall look of the curriculum and the new definition of a philosophy of education; decentralization of decision-making in their design; exclusion of Marxist-Leninist ideology, integrated in various disciplines and subjects for political indoctrination; revaluation of social subjects, particularly languages, general philosophical formation, formation and preparation of new competences previously banned but necessary for life in a democratic society, in the conditions of market economy, etc.

Improved curricula in early transition encompassed all levels of university education. So in the years 1993-1996, the activity in pre-school education were developed on the basis of "education program in kindergarten," giving priority to freedom and individualistic didactic process. This program was supported by UNICEF and had two major objectives: first in a new concept brought content of educational activities in nursery schools and secondly, to consolidate the existing network of such nurseries, during the period 1991-1992 that was greatly aggravated. With the support of AEDP began implementation of the project "Step by Step" (Step by Step preschool program in Albania, 1996: 18), initially in seven nursery schools of the Republic, as in Shkoder, Durres, Vlora, Korca, Tirana, Gjirokastra and Belsh.

The Albanian pre-university system during these years brought several curricular innovations with the help of NGOs. "Step by Step" is considered among the most successful in recent years. In the opinion of an outside evaluator: project "Step by Step" was presented successfully in Albania and is best adapted to the context of today's reality "(School is ours, 2004: 21). Another pilot project implemented in preschool system was Reggio Emilia (Lulja, E., 2009: 39), initially implemented in three nurseries: Tirana, Elbasan Lushnje and with the support of UNICEF.

In the secondary 8-year school system, one of the first curricular changes was the introduction of the new Albanian Language Textbook for the first time in the academic year 1994-1995. Curricular innovation constituted the introduction of oral courses for primary education, learning foreign languages like French, Italian, but that had largely experimental character.

Also, in the secondary 8-year school programs were introduced regarding knowledge on human and children rights, contemporary knowledge of health education, such as environmental protection, sex education, and the fight against tobacco, drugs and AIDS. It must be said that health promotion started in 10 schools and began as collaboration between the Ministry of Education (ME) and the European Network of Health. Parts of this program were even civil society such as "National Center for Health Education", "Association of Environmental Educators" etc. For the implementation of these projects during the first curricular change in 1992-1996, UNICEF and Soros gave a continuous financial contribution.

But undoubtedly the most powerful reform also entails the compulsory education curriculum that forms the basis of pre-marked after the drafting and adoption of "Strategy 2004 to 2015 for Undergraduate Education" (Memushi, L., 2003: 75). The 2004-2005 school year transition to the new system of compulsory education scheme $5+4$ initially was accomplished through the guidance of the Ministry of Education and Science (MES) and by approval of school programs and plans from this ministry. This change was not unexpected for educational facilities or districts interested in education. It should be noted that even though the law was not amended by Parliament (it was not approved the transition from secondary 8-year-old system to the 9 year old through a new form of legal guidelines in September 2004 - JS), this system took effect. (MES Annual Report, 2004-2005: 17).

By analyzing the problems of compulsory school, Education Minister of that period Mr. Luan Memushi would emphasize: "Compulsory education lasts eight years in Albania. For the duration of primary and compulsory education, Albania differs from most Western European countries. And this is one of the parameters that must be adapted according to the European standards "(MES Annual Report, 2004-2005: 37). During the treatment of this problem in the National conference, January 2004 (Memushi, L., 2003: 75), which was introduced-university National Education Strategy 20042015, it was noted that, "Changing the structure of the pre-university system ( 5 years of primary education, 4 years of secondary education and 3 for higher secondary education) dictated the reviewing of the curricula to issues that arose from time and linking it with countries in the region and the EU. Today there is a need for the conception and development of a model according to oriented curriculum requirements and acquiring the knowledge and skills needed by children, so that they feel and act as active citizens of a democratic society based on the market economy "(Memushi, L., 2003: 12).

In fact, the debates of interest groups but also in addresses of other speakers participating in this National Conference reflected a variety of reasons, which led to the passage of compulsory education from 8 to 9 years. This rep's 
on the second major change to postwar", for the time of education in basic education. One of the reasons that conditioned the restructuring of university education was "the lack of harmonization between education cycles." This change would ease the transition from a lesson with a teacher to teaching by subjects.

One of the problems identified in this period was that the unnecessary congestion reduction and avoiding premature conveying knowledge. The total number of hours in the existing plans for classes I-IX was 8054, when the draft - plan for all hours of compulsory education to nine years included even optional subjects, which were predicted about 7770 hour total (ibid.). The same is observed for the gradual increase of weekly load from class to class for lower secondary education that includes grades 6-9.

When leaving space for the activities of elective subjects in all grades for all levels (Pedagogical Magazine nr. 3 , 2004: 35), can be considered as a something new in the draft - the new teaching plan for the secondary 9-year-old system. Thus, due to the first three grades of primary education, must be said that for these activities in the curriculum it left 1-2 hours per week, for all other classes, while for first and second degree classes these activities were left free. Starting third grade, plan curriculum provides for the right of choice in the arts and physical education. In other classes, it was for all other areas. It should be emphasized that this experience is found in many lesson plans of other developed countries in Europe, which was received for review from The Institute of Pedagogical Studies (IPS).

Tab. 1: Comparison of plans in albania with some european countries in percentage

\begin{tabular}{|l|c|c|c|c|c|c|}
\hline \multirow{2}{*}{ Fields / Subject } & \multicolumn{2}{|c|}{ Old Plan\% } & \multicolumn{2}{c|}{ New Plan\% } & \multicolumn{2}{c|}{ \% Europe } \\
\cline { 2 - 8 } & CF & CMU & CF & CMU & C F & CMU \\
\hline Language and Communication & 41.5 & 27 & 35.1 & 26.5 & 33 & 26 \\
\hline Math & 21 & 15 & 21.2 & 14.1 & 19 & 13 \\
\hline Natural Sciences & 6 & 18 & 5.5 & 15.9 & 4 & 11 \\
\hline Social Sciences & 8.5 & 17.5 & 8.3 & 19.5 & 11 & 14 \\
\hline Art & 9.5 & 7 & 9.2 & 9.7 & 10 & 10 \\
\hline Technology & 5 & 7 & 4.6 & 1.8 & 5 & 8 \\
\hline PE and Sports & 8.5 & 7 & 9.2 & 7 & 8 & 7 \\
\hline Extracurricular activities & 0 & 1.5 & 6.5 & 7 & 10 & 11 \\
\hline
\end{tabular}

In high secondary education reforms had a general national objective that was to: "Provide educational preparation based on a wide differentiation of learning taking into account the full interests of the students, preparing young people for further university studies, their integration in active life of society, to assume responsibility and to exercise rights in the community framework, preparing for work "(National Strategy for Pre-University Education 2003-2004, 2003: 29).

The content of public secondary education was conceived closely related to many curricula changes primarily aimed at: "Development of a broad spectrum and flexibility, transmitting skills and knowledge to prepare them for life, filling the position of proper national character cubjects, etc." (Sota, J., Journal of Educational and Social Research (JFSR), Vol. 2, no. 2, September 2012: 132), targeting a new meaning to life and the formation of the next European citizens.

After 1992, the first was removed from the curriculum "History of the Party" and "Military Training", which had basically "Marxist orientation and changes in raw content of a particular social group" (Sota, J., Mediterranean Journal of Social Sciences (MJSS), Vol. 2, no. 3, September 2012: 96-97). In the teaching of Albanian Language and Literature, known Albanian authors such as Fishta, Konica or modern literature authors like Camus, Kafka etc. took place. In May 1995, the National Council of Literature is established, which had the primary duty modern conception of teaching material, teaching and methodical.

National Council at Ministry of Education would also function for subjects like Geography and History. It is with the changes of politics in the History Programs, in particular those related to the "History of Albania" would return to the subject ongoing debates. In 1998, under the direction of Minister of Education and Science some workshops were held. The newspaper "The Teacher" had editorials from specialists, University of Tirana professors, employees of the Institute of History, or representatives of the different foundations etc. (The Teacher, March 18, 1998). Curriculum debates, but also to the selection criteria for participating groups in the process of curriculum development history, would find reflection

\footnotetext{
* The first belongs to academic year 1963-1964, when ocurred the transfer from 7 year secondary educational system to 8 year (Sota, J., 2012: 392). 
in professional publications of IPSs, especially in sections of pedagogical rubrics. Thus, in one of these journals, one of the authors wrote that, "compiling of history curricula look like an integral part of the strategy for reforming our education system, which is implemented in accordance with the socio-economic needs of today's prospects and our state education policy for education of the young generation" (Pedagogical Journal, no. 2, 2002: 70).

The process reduces the changes of history over the 1990's, which was characterized by attempts to establish more equitable ratio between political, military and diplomatic aspects on the one hand and the social, economic and cultural shift in world and national history (Sota, J., Journal of Educational and Social Research (JFSR), Vol. 2, no. 1, January 2012: 172). New textbooks were developed by avoiding Marxist content. Likewise, a group of subjects that were not previously introduced included: "Sociology", "Economics", "Introduction to the History of Philosophy", "Informatics". In this framework, a textbook was produced for every class and more than 80 published were new texts (ibid: 173). In the academic year 1998-1999, "Information Technology" was introduced for the first time to the learning process, in 85 schools (ibid.).

It must be said that improving school programs and the introduction of elements of civic education continued after 2000. Such a new program was the "Human Rights Education Project", which was extended to entire education system in the country since 2001 "(Sota, J., Mediterranean Journal of Social Sciences - Special Issue, Vol. 4, no. 4, March 2013 : 84).

In the 1999-2000 academic year, the curriculum underwent changes. It underwent a partial experimentation phase before implementation. Thus, in 15 schools that belonged to 11 different Districts of the country (Pedagogical Magazine, No.1-2, 2000: 4 5), began implementation the profiling of the general high school. In view of this experiment, were erected and exercised the central group, the curricula group, material and financial establishment group resources, subject-specific committees and commissions for profiling at Education Directories (ED) of Districts (Pedagogical Magazine, NO. 1, 2002: 21).

Curricula Group developed curriculum syllabus, which was approved by the MES. Commissions developed and approved subject curriculum and School Text Publishing House* developed experimental textbooks for profiled schools. In the span of three years from the start of profiling in the form of an experiment, a series of articles were written by various education specialists. Bringing their vision for profiling and then their experiences these specialists not only helped to enrich the conceptual view of profiling but also were associated with concrete work. However, the early years of experimentation were highlighted some of the basic problems. Thus, in the main cities of Albania, particularly in Tirana, it was the concern that constituted of "large number of student per class, which would put into question the progress of the experiment" (Teacher, October 2002).

Another highlighting problem to profiling, concerned training activities organized by MES, IPS or any nonprofit organization in the field of education. In the first year of the experiment, SOROS Foundation in cooperation with IPSs and MES would conduct two seminars in order of "recognition of the teaching material of the chapters that will be addressed in school, in the near perspective" (Report of the DMA on profiling, Tirana, 2000: 17). There were also offered some alternative didactic proceedings as useful for treating certain class on the hardest topics. But the performance training workshops continued with the same pace in the later years of experimentation.

By the end of the academic year, the Ministry of Education organized several "special annual analysis for profiling experiment on a whole" (ibid), for all steps taken, achievements, gaps, setting the experimental tasks for the coming year. In them, were approved in principle, experimental annual work plans for all institutions involved in profiling (ibid).

2001-2002 academic year, would concretize the experiment, thus ensuring the separation into two profiles: social and natural. Regardless, that was in itself filled with many unknown sights to all stakeholders involved, MES consistently explained that despite following profile, students have the right to attend any of the programs of study offered at all Higher Public Education Institutions (HPEI). On the other hand, it pointed out the fact that according to the policies pursued for admission to HPEI profiles, students would have the advantage of various programs of study. Further, this policy would materialize clearly the creation of "Matura", to which this working paper carries on.

Meanwhile, under the direction of teachers, on the basis of 2 years performance and their knowledge of trends, profiles defined what would be more convenient to be followed by each student (ibid). Each student through headmasters was made known this recommendation but it was the student who would decide what choices to be made. In many cases, schools were put in difficulty by the indecision of a group of students who were in need of their decision.

It should be emphasized that the 2010-2011 academic years would mark the end of secondary education profiling, which in most of the estimates is considered "a failed experiment" (Lule, E., 2009: 303). This relates to the fact that, "Choice was in two large blocks and does not take into account the specific interests within a direction, social or natural,

* The only institution of the time for school publishing. 
which affect adolescents in trends and their real needs, coupled with a higher load of learning materials" (Gjedia, R., Hamza, M., Pedagogical Journal , no. 2, Tirana, 2009: 7). Another shortcoming was pointed out by education specialists, related to the fact that high school did not provide profiles about vocational education, it does not allow the addition to preparing for university students preparing towards an apprenticeship or job profile required by the market labor. But referring to curricular changes, it is thought that it was a step forward in comparison with legacy models, because instead of a same curriculum for all students, it went for the first time in elections by themselves.

Changing the duration of compulsory education law, from 8 to 9 years, would determine the new changes in the structure of AMP. Already since the 2009-2010 academic years, AMP has gone from 4 years to 3 years. This year, it should be noted that the $10^{\text {th }}$ grade began implementing the new curriculum (Guide for the development of new high school curriculum, 2010: 12).

In this context, the MES adopted a new curriculum, ending the period of profiled high schools. Approval by CM, DCM No. 538, and dated 12.08.2004 of the National Strategy for Development of Pre-University System from 2004 to 2015, will pave the task of designing and implementing a new curriculum. Implementation of this requirement means the transition from commodity-based curriculum that is based on the results of students (Undergraduate Education Strategy 2004-2015, 2004: 18.). Implementation of the curriculum framework was charged with this task the IPS.

\section{Conclusions}

According to curriculum reform of 2009-2010, an important process of reforming undergraduate education content is already under way. Although, to talk about the results and the quality of curricula it should start drafting the curriculum that involves the way it conceives the curriculum and organization of its main elements (subject, the content, methods and materials, and experiences of students) as and its implementation. Given the complexity of the curriculum as a process of defining and designing content from different angles and during a long stagnation of reforms, the process of drafting is long and complicated.

Although the plan curriculum are planned and set to change about $80 \%$ by MES, the autonomy of only $10-20 \%$ is left to schools to design and organization of elective courses based on merit and student preferences. However, implementation of elective courses is related deficiencies in schools, which do not have the budget for implementing elective courses, although many requests of students require significant investment in school or elective courses to meet current fund of school teachers resulting in same area subjects or unqualified ones. Efficacy of genuine responsibility and accountability is a real necessity for the implementation of new curricula and school success. This is reflected by the increase of responsibility of teachers and monitoring, as consequence increase of quality. Given the motive and policies related to wage growth, responsibility towards work and implementation of standards that teachers should meet for effective and quality work, it is thought that it should be transferred and monitored. This obviously enables schools to identify quality improvement unit in this process.

For pre-university system monitoring and accountability must be an undivided part of real quality curriculum implementation. As Furhman and Elmore stresses (2004) ${ }^{82}$, for an improved systematic accountability system, it should generate and focus attention on the new information of contemporary teaching and learning, to motivate teachers and to increase efforts for implementation of developmental knowledge and skills, to inaugurate valuable information interpretations and to achieve a long-term quality and durability. Such a precaution may result in elimination of consequences associated with stagnation of instructional change or non-classification of schools and teachers. In this context, it is believed that monitoring should be organized and qualitative because the actors who participate in the education process and education play here a role in charge of a structured format that should use monitoring.

One of the greatest innovations in the process of reforming the curriculum and a positive approach are achievement of standards that guide teachers and students towards learning and standardizing capabilities. Since reaching the standard of achievement is measured by assessing the external and internal aspects, in the Albanian context it is thought that these two estimates should achieve the right quality at the proper external evaluation implemented only in $9^{\text {th }}$ grade and the test is mainly made of alternative questions, the application of diverse methods of assessment that are provided with the new curricula's; in teacher training in diversified assessment, the use of concurrent tests with accessibility standards. All these, make that educational institutions play a key role in the development of the Albanian society. 


\section{References}

\section{Archive}

Central State Archive of the Republic of Albania (CSARA). Fondi: 511, Ministry of Education (1945-1988)

\section{Documentary Sources Published}

"Problems and promise", Albania's Education Sector, Tiranë, 2000

Law Nr. 7952, date 21. 6. 1995, "On pre-university education in the Republic of Albania" (adjourned)", Article 25, Parliament of Albania, Tirana, 1995

Law Nr. 9741, date 21. 5. 2007, "On Higher Education in the Republic of Albania (adjourned)", Parliament of Albania, Tirana, 2007

Report of the Task Force on Education "On a thematic review of national policies for education Albania", edition of MES, Tirana, 2002

Education Statistical Report 2002-2003, published by MES, Tirana 2003

Education Statistical Report 2005-2006, published by MES, Tirana 2006

Education Statistical Report, 2003-2004, edition of MES, Tirana, 2004

Step by Step preschool program in Alban, An Evaluation Report, Tirana, 1996

Undergraduate Education Strategy 2004-2015, Ministry of Education and Science, Tirana 2004

National Strategy Education references have Parauniversi 2009-2013, edition of MES, Tirana 2009

National Strategy Education references have Parauniversi2007-2013, edition of MES, Tirana 2007

National Strategy references have 2004-2015 Undergraduate Education, a publication of MES, Tirana 2004

\section{Periodical}

Mësuesi: 1996, 1999, 2002, 2003. 2006. 2007, 2009, 2010, 2012,02013

Shekulli: 200, 2005, 2006. 2007, 2009

Administrimi dhe Menaxhimi i Arsimit, nr. 2, Tiranë, 2002

Revista Pedagogjike, nr. 2, Tiranë, 1998

Revista Pedagogjike, nr. 1, Tiranë, 2002

Revista Pedagogjike, nr. 2, Tiranë, 2002

Revista Pedagogjike, nr. 3, Tiranë, 2004

Revista Pedagogjike, nr. 3,Tiranë, 2005

Revista Pedagogjike, nr. 3,Tiranë, 2006

Revista Pedagogjike, nr. 2,Tiranë, 2007

Revista Pedagogjike, nr. 3,Tiranë, 2007

Revista Pedagogjike, nr. 4, Tiranë, 2007

Revista Pedagogjike, nr. 1, Tiranë, 2009

Revista Pedagogjike, nr. 2, Tiranë, 2009

Probleme Psiko-Pedagogjike e Sociale, nr. 2, Tiranë, 2002

\section{Historic Literature}

Bejtja, P., Mustafaj, A., Zagoria, E., Dimas, L., (1999/2000). Reforming the Curriculum of Education and Vocational Training in Albania Study Material

The Curriculum on School Basis (The curriculum Module), Tirana, 2007.

Earl. L., Lee, L., (1998). School Improvementâ: What Have We Learned From the Manitoba Experience, Toronto, Walter and Duncan Gordon Foundation

Address by the Minister of Education and Science, Mr. Plays Memushi, January 2004

Group of authors, Educational Reform in Countries of Central and Eastern Europe (1995). Institute of Pedagogical Studies, Tirana

Paluka, llia., Nishku Agron., National Conferences Scalps Tarna, 2009

Law on Undergraduate Education in the Republic of Albania, 7952, dated 21.06.1995. Article 30.2.

Plays Memushi, School Reform, Process and Strategy, Tirana 2003

Flower, E., (2009). Thoughts on Education Reform, Filaret, Tirana

Model Curriculum Based on the Results, the Institute of Pedagogical Studies, Tirana

National Strategy for Pre - University Education Development 2007-2013, Tirana 2007

Annual Report of the Ministry of Education and Science 2004-2005, Tirana 2004

DMA Report, Profiling, Tirana, 2000, 2001

Annual Report of the City of Tirana DA, 2000

Links to Health Education, in: Teacher, 1995, 1996 
Sota, J. (2014), Educational Developments in the District of Fier, "Extra", Tirana

School is ours, Tirana: "Maluka", 2004

Guidelines to MA

Guidelines for the Development of New High School Curriculum, ICT

Office of Protocol, Ministry of Education and Science of Tirana

\section{Articles}

"Perspective of history", in: Teacher, Tirana, 18 March 1998.

"Section on profiling AMP throughout the year from 2001 to 2002), "Teacher, October 2002

Çuko. R., Kreci, N., "The performance of the experiment "AMP Profiling", Journal Pedagogical No.1, Tirana, 2002

Epstein, J., Coates, L., Salinas, M., Simon, B., (1997). School. Family and Community Partnership, Your Handbook for Action, Thosand Oakes, CA, Corwin Press

Gjedia, R., Hamza, M., "The nNw High School Curriculum and it's Implementation in School", Journal Pedagogy, 2, Tirana, 2009

Hamza, M., Sefa, Y., "Approaches to School-Based Curriculum", School-Based Curriculum. Modular Curricula, Publication of Curriculum and Standards Institute, Tirana, 2007

Nishku, A., "Effect Curriculum as a Way of Planning and Programming Lessons of History", Journal Pedagogy, No. 1, Tirana, 2002

Sota, J, "Approaches and On the Ratio Differences Between History and Sociology", Mediterranean Journal of Social Sciences (MJSS), Vol. 2, No. 3, September 2012

Sota, J, "Efficiency and Effectivenees of Pre-University Education in the Optics of Human Capital", Beder University of Educational Sciences, Vol. 2, Apriel 2013

Rama, F, Papajani, A., " Basic Directions for the History Curriculum of Albania", Journal Pedagogy, no. 2, Tirana, 2002

Sota, J., "New State Policy to National Minorities on Educational and Cultural Viewpoint After 1990, Mediterranean Journal of Social Sciences - Special Issue, Vol. 4, no. 4, March 2013

Sota, J., "Educational Phenomena in Albania in the Years of Communist Dictatorship and the reformatio Efforts after the Nineties ", Journal of Educational and Social Research (JFSR), Vol. 2, No. 2, May 2012

Sota, J., " International Organizations and theire Contribution to the School Development and Contemporary Education in Albania ", Journal of Educational and Social Research (JFSR), Vol. 2, no. 2, September 2012

Sota, J., "The Role of Historical Resources in Teaching of History at the English Schools After 90-s", Journal of Educational and Social Research (JFSR), Vol. 2, No. 1, January 2012

Soter, R., Yllka, S., "The Advantage of Draftplanit the 9 -year Compulsory education, Journal Pedagogy, no. 3, 2004

\section{Abbreviations Used}

APRIAL - National Agency of Admissions in Institutions of Higher Educatio

AVA - Assessment Agency Arritjve

WB - World Bank

CARDS - ommunity Assistance for Reconstruction, Development and Stabilisation

CBA - Excellence and Equity in Education

DAR - Regional School District

EFA - Education for All

GNP - Gross National Product

ICS - Institute of Curriculum and Standards

ICT - Curriculum and Training Institute

INSTAT - Institute of Statistics

LSMS - Assessment Study of Living Standards

MOES - Ministry of Education and Science

OECD - Organization for Economic Cooperation and Development

NGO - Non-Governmental Organization

NCEE - National Center for Education Evaluation and Assessment

ETQC - Training Centre for Education and Training

DDPASP - Dapps Department of Policy Analysis and Strategic Planning

SKZHAP - National Strategy for Development of Pre-University Education

ICT - Information and Communication Technology

UNICEF - The United Nations Fund for Children

COM - Decision of the Council of Ministers

ZA - Educational Office 